\title{
Effect of Nitrogen, Zinc and Boron on Nutrient Concentration at Maximum Tillering of Wheat
}

\author{
Rana SS*1, Sanjay K Sharma ${ }^{2}$ and Sapna Kapoor ${ }^{2}$ \\ ${ }^{1}$ Department of Agronomy, CSK HP Agricultural University, Palampur, India \\ ${ }^{2}$ Department of Soil Science, CSK HP Agricultural University, Palampur, India
}

Received: December 01, 2017; Published: December 08, 2017

*Corresponding author: SS Rana, Department of Agronomy, Forages and Grassland Management, CSK HP Agricultural University, Krishi Vishvavidyalaya, Palampur 176 062, HP India; Email: ranassdee@gmail.com

\begin{abstract}
A field investigation was carried out at Palampur with sixteen treatment combinations consisting of four levels of $N(0,50,100$ and150 per cent of recommended dose), two levels of $\mathrm{Zn}\left(0\right.$ and $\left.10 \mathrm{~kg} \mathrm{ha}^{-1}\right)$ and two levels of B ( 0 and $\left.1 \mathrm{~kg} \mathrm{ha}^{-1}\right)$ in factorial randomized block design. Highest grain ( $45.83 \mathrm{q} \mathrm{ha}^{-1}$ ) yield of wheat was recorded under 150 per cent of recommended dose of nitrogen which was 84.8 per cent higher than control. Application of $10 \mathrm{~kg} \mathrm{Zn} \mathrm{ha-1}$ increased the grain yield by 9.7 per cent. Similarly, boron application @ $1 \mathrm{~kg} \mathrm{ha}^{-1}$ increased grain yield by 8.1 per cent. In general, application of nitrogen increased the concentrations of $\mathrm{N}, \mathrm{P}, \mathrm{K}, \mathrm{Mn}, \mathrm{Fe}, \mathrm{Cu}, \mathrm{Zn}$ and B in plants at maximum tillering of wheat. $\mathrm{N}, \mathrm{K}, \mathrm{Mn}, \mathrm{Cu}$ and $\mathrm{B}$ concentration of wheat at maximum tillering increased with increasing level of nitrogen upto $150 \%$ recommended dose of nitrogen. P concentration increased upto $100 \%$ dose of nitrogen while $\mathrm{Zn}$ and Fe concentration increased upto $50 \%$ recommended dose of nitrogen. Application of Zn @ 10kg ha-1 resulted in increased N, K, Zn and B concentrations and decreased Fe, Mn and Cu concentrations. P concentration in plants of wheat at maximum tillering was not affected significantly due to Zn application over no Zn application. Boron @ 1kg ha $^{-1}$ significantly increased $\mathrm{N}, \mathrm{P}, \mathrm{K}, \mathrm{Zn}$ and B concentrations at maximum tillering of wheat.
\end{abstract}

Key words: Nitrogen; Zinc; Boron; Nutrient Concentration; Maximum Tillering; Wheat

\section{Introduction}

A crop absorbing enough of plant nutrients is expected to yield higher than a crop accumulates lower nutrients. Thus estimating nutrient concentrations is essentially an important task to have strategies for sustained higher yields. Nitrogen is one of the major plant nutrients and is an essential constituent of all living cells. It plays a number of functions in the plant growth as it is a constituent of proteins, enzymes and chlorophyll, and takes part in metabolic processes involved in the synthesis and transfer of energy. Its importance in crop production is emphasized by the knowledge that nitrogen generally occurs in relatively small quantities in soils in the available forms and is used in large quantities. However, continuous heavy application of only one nutrient disturbs the nutrient balance and leads to depletion of other nutrients as well as the underutilization of nutrients supplied through fertilizers. Single nutrient approach has often caused reduced fertilizer use efficiency and consequent problems of multiple nutrients deficiencies in cerealbased cropping systems. Accelerated depletion of micronutrients from soil reserve due to enhanced food grain production has accentuated the micronutrients deficiencies in many parts of India, which has brought sharp reduction in the macronutrient (NPK) use efficiencies Shukla [1-3].

Nearly 50 per cent of the Indian soils are deficient in zinc and likely to respond to its application. Deficiency of boron (33 per cent) follows zinc with one-third of the soil samples falling in deficient category Katyal. Responses to applied zinc and boron have been obtained across the soils in different agro-ecological regions of country. In view of imparting sustainability to the crops and cropping systems, incorporation of these products along with major NPK fertilizers open up new area of research. The high rainfall conditions prevalent in zone-II of Himachal Pradesh may favour the losses of these micronutrients. Their application in soil is expected to improve the crop productivity and may influence the use efficiency of macronutrients particularly of nitrogen. Keeping these facts in view, the present study was planned to reveal the influence of nutrients application in soil on nutrient concentrations on plants and subsequent effect of yield of wheat under mid hill conditions of Himachal Pradesh. 


\section{Materials and Methods}

A field experiment was conducted at the Experimental Farm of the Department of Soil Science, CSK Himachal Pradesh Krishi Vishvavidyalaya, Palampur $\left(32^{\circ} 6 \otimes \mathrm{N}\right.$ latitude $76^{\circ} 3 \otimes \mathrm{E}$ longitude and $1290 \mathrm{~m}$ altitude) during rabi 2010-2011. The area is characterized by wet temperate climate having severe winter and mild summer with mean annual temperature from $10.4^{\circ} \mathrm{C}$ in January to around $30^{\circ} \mathrm{C}$ during May-June. The average annual rainfall ranges between 1500 to $3000 \mathrm{~mm}$, out of which about 80 per cent is received during June to September. The mean relative humidity in the region varies from 29 to 84 per cent, the minimum being in April and maximum in July and August. The soil of experimental site was Typic hapludalf and acidic in reaction with $\mathrm{pH}$ value of 5.3. The experimental soil was silty clay loam in texture, medium in organic carbon, low in available $\mathrm{N}$ and medium in available $\mathrm{P}$ and $\mathrm{K}$. The contents of DTPA extractable $\mathrm{Fe}, \mathrm{Mn}$ and $\mathrm{Cu}$ were adequate whereas DTPA Zn was marginally adequate and hot water soluble B was insufficient. Sixteen treatment combinations were replicated thrice in factorial RBD and comprised four levels of nitrogen $(0,50,100$ and 150 per cent of recommended dose of $\mathrm{N}$ ), two levels of zinc ( 0 and $10 \mathrm{~kg}$ ha1) and two levels of boron ( 0 and $1 \mathrm{~kg} \mathrm{ha}^{-1}$ ).
Recommended dose of $\mathrm{N}, \mathrm{P}_{2} \mathrm{O}_{5}, \mathrm{~K}_{2} \mathrm{O}$ for wheat is $120,60,30 \mathrm{~kg}$ $\mathrm{ha}^{-1}$. Half dose of $\mathrm{N}$ and full dose of $\mathrm{P}, \mathrm{K}, \mathrm{Zn}$ and $\mathrm{B}$ were applied at sowing time. The remaining half dose of $\mathrm{N}$ was top dressed at $30 \mathrm{DAS}$. The sources of N, P, K, Zn and B were urea, single superphosphate, muriate of potash, zinc oxide and borax, respectively. The wheat variety 'HPW-155' was sown on $29^{\text {th }}$ November 2010 and harvested on $25^{\text {th }}$ May 2011. The crop was grown with recommended package of practices under irrigated conditions. The wheat plant samples were collected at maximum tillering stage. Grain and straw samples were collected during threshing. The wheat plant samples collected at tillering stage and grain and straw samples collected after the harvest were brought to laboratory fresh. Then washed immediately in order to make them free from dust or any other adhering substances. Samples were first washed under running tap water. Subsequently, these samples were washed with acidified distilled water (1ml concentrated $\mathrm{HCl}$ per liter) followed by thorough rinsing twice with distilled water. The samples were then dried in an oven at $60^{\circ} \mathrm{C}$. The dried samples were then ground in a grinder fitted with stainless steel parts to pass through $1 \mathrm{~mm}$ sieve. These are then kept in paper bags for subsequent analysis. The detail of methods employed for chemical analysis is given below in (Table 1).

Table 1: The methods used for determination of nutrient concentration in plant samples.

\begin{tabular}{|c|c|}
\hline Parameter & Method employed \\
\hline Nitrogen & Digestion with concentrated $\mathrm{H}_{2} \mathrm{SO}_{4}$ in the presence of digestion mixture $\left(\mathrm{K}_{2} \mathrm{SO}_{4}, \mathrm{CuSO}_{4}\right.$ and Selenium powder in \\
\hline Phosphorus & $\begin{array}{c}\text { Digestion in diacid mixture }\left(\mathrm{HNO}_{3} \text { and } \mathrm{HClO}_{4} \text { in 9:4 ratio) and further determination following vanadomolybdate acid yellow }\right. \\
\text { colour method (Jackson 1973). }\end{array}$ \\
\hline Potassium & Digestion in diacid mixture and further estimation by flame photometric method Black [2]. \\
\hline Boron & $\begin{array}{l}\text { Digestion by dry ashing in muffle furnace at } 550 \mathrm{oC} \text { for } 2 \text { hrs followed by digestion with } 6.0 \mathrm{~N} \mathrm{HCl} \text { and further determination } \\
\text { using carmine method Hatcher and Wilcox [3] }\end{array}$ \\
\hline Mn, $\mathrm{Zn}$ and $\mathrm{Cu}$ & Digestion in di-acid mixture and further estimation using atomic absorption spectrophotometer (AAS) Jackson [1] \\
\hline
\end{tabular}

\section{Results and Discussion}

\section{Nutrient Concentration at Maximum Tillering}

Application of nitrogen significantly affected its per cent concentration in plants of wheat at maximum tillering (Table 2). The variation in concentration of nitrogen was 1.63 per cent under no nitrogen application $\left(\mathrm{N}_{0}\right)$ to 2.35 per cent under the treatment receiving super optimal dose of nitrogen $\left(\mathrm{N}_{150}\right)$. This substantial increase can be due to increased $\mathrm{N}$ availability enabling plants to take up more nitrogen. Secondly, N application might have increased the root growth which favoured more removal of nitrogen by wheat plants. Zinc application @ $10 \mathrm{~kg} \mathrm{ha}^{-1}$ resulted in significant increase in nitrogen concentration of wheat tillers. It increased from 1.91 per cent under no $\mathrm{Zn}$ application to 2.01 per cent under $\mathrm{Zn}_{10}$. This increase in nitrogen concentration might be attributed to better plant growth as zinc helps in nitrogen absorption due to synergistic relationship between nitrogen and zinc. Similar findings were obtained by AbdEl-Hady [4]. Application of boron @ $1 \mathrm{~kg}$ ha $^{-1}$ significantly influenced nitrogen concentration over no B application. Nitrogen concentration increased from 1.94 per cent under $\mathrm{B}_{0}$ to 1.98 per cent under $\mathrm{B}_{1}$, respectively. It might be due to the role of boron in the absorption of nitrogen Das [5].

Table 2: Effect of nitrogen, zinc and boron on macro (\%) and micronutrient concentration (mg kg-1) at maximum tillering and grain yield of wheat.

\begin{tabular}{|c|c|c|c|c|c|c|c|c|c|}
\hline Treatment & $\mathbf{N}$ & $\mathbf{P}$ & $\mathbf{K}$ & $\mathbf{Z n}$ & $\mathbf{M n}$ & $\mathbf{F e}$ & $\mathbf{C u}$ & $\mathbf{B}$ & $\mathbf{G r a i n}$ \\
\hline $\begin{array}{c}\text { Nitrogen (\% of } \\
\text { recommended } \\
\text { dose) }\end{array}$ & & & & & & & & \\
\hline $0\left(\mathrm{~N}_{0}\right)$ & 1.63 & 0.32 & 1.25 & 22.08 & 63.16 & 103.63 & 25.83 & 13.07 & 24.79 \\
\hline $50\left(\mathrm{~N}_{50}\right)$ & 1.73 & 0.34 & 1.33 & 25.25 & 68.19 & 116.13 & 30.17 & 14.17 & 36.59 \\
\hline $100\left(\mathrm{~N}_{100}\right)$ & 2.13 & 0.36 & 1.39 & 26.75 & 75.46 & 121.50 & 33.75 & 16.92 & 41.14 \\
\hline $150\left(\mathrm{~N}_{150}\right)$ & 2.35 & 0.36 & 1.44 & 26.75 & 81.68 & 124.88 & 35.67 & 18.04 & 45.83 \\
\hline
\end{tabular}




\begin{tabular}{|c|c|c|c|c|c|c|c|c|c|}
\hline LSD $(\mathrm{P}=0.05)$ & 0.04 & 0.01 & 0.04 & 2.09 & 3.80 & 10.33 & 1.26 & 0.44 & 2.19 \\
\hline Zinc $\left(\mathrm{kg} \mathrm{ha}^{-1}\right)$ & & & & & & & & \\
\hline $0\left(\mathrm{Zn}_{0}\right)$ & 1.91 & 0.34 & 1.34 & 23.17 & 73.47 & 123.31 & 31.88 & 15.00 & 35.37 \\
\hline $10\left(\mathrm{Zn}_{10}\right)$ & 2.01 & 0.35 & 1.37 & 27.25 & 70.77 & 109.75 & 30.83 & 16.00 & 38.81 \\
\hline LSD $(\mathrm{P}=0.05)$ & 0.03 & NS & 0.03 & 1.48 & 2.68 & 7.30 & 0.89 & 0.31 & 1.55 \\
\hline Boron $\left(\mathrm{kg} \mathrm{ha}^{-1}\right)$ & & & & & & & & \\
\hline $0\left(\mathrm{~B}_{0}\right)$ & 1.94 & 0.33 & 1.34 & 24.42 & 71.27 & 113.88 & 30.96 & 14.91 & 35.63 \\
\hline $1\left(\mathrm{~B}_{1}\right)$ & 1.98 & 0.36 & 1.37 & 26.00 & 72.97 & 119.19 & 31.75 & 16.19 & 38.54 \\
\hline LSD $(\mathrm{P}=0.05)$ & 0.03 & 0.01 & 0.03 & 1.48 & NS & NS & NS & 0.31 & 1.55 \\
\hline
\end{tabular}

The phosphorus concentration of wheat at maximum tillering increased with increasing level of nitrogen upto 100 per cent recommended dose of nitrogen. Further increase in $\mathrm{N}$ level $\left(\mathrm{N}_{150}\right)$ did not increase the $\mathrm{P}$ concentration of wheat tillers over its preceding level. Similar results were reported by Yadav [6]. However, application of $\mathrm{Zn}\left(\mathrm{Zn}_{10}\right)$ could not increase phosphorus concentration of wheat at maximum tillering over no $\mathrm{Zn}$ application $\left(\mathrm{Zn}_{0}\right)$. Boron application @ $1 \mathrm{~kg} \mathrm{ha}^{-1}$ resulted in significant increase in phosphorus concentration. The increased $\mathrm{P}$ concentration might be due to the favourable effect of B which alters the permeability of plasma lemma at the root surface in such a way that $\mathrm{P}$ absorption increases Patel and Golakiya [7]. Nitrogen application resulted in higher $\mathrm{K}$ concentration. The maximum concentration (1.44 per cent) was recorded at highest rate of nitrogen application $\left(\mathrm{N}_{150}\right)$ which was significantly better over rest of the $\mathrm{N}$ levels $\left(\mathrm{N}_{0}, \mathrm{~N}_{50}\right.$ and $\mathrm{N}_{100}$ ). The results are in accordance with those reported by Yadav [6]. K concentration also significantly increased with application of zinc @ 10 kg Zn ha ${ }^{-1}$. Similar results with application of zinc on $\mathrm{K}$ concentration in plants were reported by AbdEl-Hady. Similarly, application of boron @ 1 $\mathrm{kg} \mathrm{ha}^{-1}$ increased potassium concentration at maximum tillering (1.37 per cent) over no boron application (1.34 per cent). Slight increase in K content with boron application may be due to the fact that it depresses the uptake of Ca which otherwise has antagonistic effect on $\mathrm{K}$ as reported by Reeve and Shive [8].

$\mathrm{Zn}$ concentration increased from $22.08 \mathrm{mg} \mathrm{kg}^{-1}$ under $\mathrm{N}_{0}$ to $26.75 \mathrm{mg} \mathrm{kg}^{-1}$ under $\mathrm{N}_{100}$. Further increase in $\mathrm{N}$ level to 150 per cent of recommended nitrogen did not increase the concentration of $\mathrm{Zn}$ any more. The increase in $\mathrm{Zn}$ concentration might be due to synergistic effect between nitrogen and zinc as adequate supply of $\mathrm{N}$ enhanced the translocation of $\mathrm{Zn}$ from roots to other parts of plants. Further better root and shoot growth with the application of $\mathrm{N}$ might have led to better utilization of the zinc and other cations from the soil solution. Similar results were reported by and Lin et al. [9]. Zinc concentration increased with the increase of zinc in nutrient solution. Application of zinc @ 10kg ha-1 $\left(\mathrm{Zn}_{10}\right)$ resulted in significantly higher zinc concentration $\left(27.25 \mathrm{mg} \mathrm{kg}^{-1}\right)$ over no zinc application $\left(23.17 \mathrm{mg} \mathrm{kg}^{-1}\right)$. The increase in $\mathrm{Zn}$ concentration with the application of $\mathrm{Zn}$ may be attributed to its enhanced supply through ZnO added externally. Ai-Qing et al. [10] also reported an increase in zinc concentration with its addition. B increased the zinc concentration by18 per cent over no application of B. Similar results were reported by Kaur [11]. Manganese concentration increased consistently from $63.16 \mathrm{mg} \mathrm{kg}^{-1}$ under $\mathrm{N} 0$ to $81.68 \mathrm{mg} \mathrm{kg}^{-1}$ under $\mathrm{N}_{150}$.

Per cent increase in Mn concentration due to application of 50, 100 and 150 per cent of recommended $\mathrm{N}$ was 7.9, 19.4 and 29.3, respectively. Similar observations were reported by Lin et al. [9]. Mn concentration decreased with the application of zinc @ 10kg ha-1 $\left(\mathrm{Zn}_{10}\right)$. It might be because of negative effect of zinc on translocation of Mn as reported by Narwal and Malik [12]. Boron application could not significantly influence Mn concentration at maximum tillering of wheat. Iron concentration at maximum tillering increased with the application of nitrogen. It ranged from $103.63 \mathrm{mg} \mathrm{kg}^{-1}$ under control to $124.88 \mathrm{mg} \mathrm{kg}^{-1}$ under $\mathrm{N}_{150}$. However, the increase was not consistent above the application of 50 per cent of recommended $\mathrm{N}$ as the differences among N levels (50-150 per cent of recommended N) were not significant. Application of zinc @ 10 kg ha-1 decreased iron concentration at maximum tillering from $123.31 \mathrm{mg} \mathrm{kg}^{-1}$ under $\mathrm{Zn} 0$ to $109.75 \mathrm{mg} \mathrm{kg}^{-1}$ under $\mathrm{Zn}_{10}$. This indicated mutual antagonism between these two nutrients. The antagonistic relationship might be attributed to the competition of $\mathrm{Fe}^{2+}$ with $\mathrm{Zn}^{2+}$ at absorption sites of roots causing inhibition in absorption of each other and also resulting in ionic imbalance. The ferrous $\left(\mathrm{Fe}^{2+}\right)$ iron competes with zinc $\left(\mathrm{Zn}^{2+}\right)$ in the uptake process for formation of chelates or other reactions Sinha and Sakal [13]. Similar results were reported by Ai-Qing et al. [10] in wheat. Application of boron increased Fe concentration under $B_{1}\left(119.19 \mathrm{mg} \mathrm{kg}^{-1}\right)$ over $\mathrm{B}_{0}\left(113.88 \mathrm{mg} \mathrm{kg}^{-1}\right)$ but the difference was not significant.

There was significant and consistent increase in Cu concentration in wheat tillers with increased levels of nitrogen from $25.83 \mathrm{mg} \mathrm{kg}^{-1}$ under $\mathrm{N}_{0}$ to $35.67 \mathrm{mg} \mathrm{kg}^{-1}$ under $\mathrm{N}_{150}$. Application of 50, 100 and 150 per cent of recommended dose of $\mathrm{N}$ increased $\mathrm{Cu}$ concentration in wheat tillers by 16.8, 30.6 and 38.0 per cent, respectively. This might be due to better root and shoot growth and healthy plants in presence of higher nitrogen levels. As a result the plants might have taken up higher amount of nutrients including copper. Similar observations were reported by Lin et al. [9]. However, application of zinc @ $10 \mathrm{~kg} \mathrm{ha}^{-1}$ significantly reduced copper concentration in plant at maximum tillering. The decreased $\mathrm{Cu}$ concentration with $\mathrm{Zn}$ application might be attributed to antagonism of zinc $\left(\mathrm{Zn}^{2+}\right)$ and copper $\left(\mathrm{Cu}^{2+}\right)$ ions having same ionic radii and charge which compete with each other for the absorption sites in the plasma membrane of roots as both ions have been found to be absorbed by the same transport system Choudhary et al. [14]. Copper 
concentration varied from 30.96 at $\mathrm{B}_{0}$ and 31.75 at $\mathrm{B}_{1}$, however the increase in $\mathrm{Cu}$ concentration was not significant.

Boron concentration at maximum tillering increased significantly and consistently with increase in nitrogen level from 0 to 150 per cent of the recommended dose and values ranged from $13.07 \mathrm{mg} \mathrm{kg}^{-1}$ under control to $18.04 \mathrm{mg} \mathrm{kg}^{-1}$ under $\mathrm{N}_{150}$. Application of 50, 100 and 150 per cent of recommended dose of $\mathrm{N}$ increased B concentration in wheat tillers by 8.4, 29.4 and 38.0 per cent, respectively. This could be due to more vegetative growth and root growth, which release root exudates resulting in increased boron availability in soil and finally the uptake by plants. The results of the investigation are in consonance with the findings of Hellal et al. [15]. Application of zinc @ $10 \mathrm{~kg} \mathrm{ha}^{-1}$ also enhanced the boron concentration at maximum tillering from $15.0 \mathrm{mg} \mathrm{kg}^{-1}$ under $\mathrm{Zn}_{0}$ to 16.0mg kg-1 under Zn10. Similar results have been reported by Kaur [11]. Likewise, boron application increased boron concentration significantly from $14.91 \mathrm{mg} \mathrm{kg}^{-1}$ under $\mathrm{B}_{0}$ to $16.19 \mathrm{mg} \mathrm{kg}^{-1}$ under $\mathrm{B}_{1}$. The per cent increase in B concentration was worked out to 13.4 over no B application. The increase in boron concentration may be ascribed to increased availability of boron through the addition of borax.

\section{Grain Yield}

There was consistent increase in grain yield of wheat upto $150 \mathrm{~kg}$ $\mathrm{N}$ ha-1. Application of 50, 100 and 150 per cent of recommended dose of $\mathrm{N}$ increased the grain yield of wheat by 47.5, 65.9 and 84.8 per cent, respectively over the control. Increase in yield by $\mathrm{N}$ might be due to increased vegetative growth, more synthesis of carbohydrates and their translocation for the synthesis of organic nitrogen compounds which are constituents of protoplasm and chloroplasts. The results are substantiated by the findings of the studies conducted by Mattas et al. [16] and Roshan et al. [17] at different locations. Significantly higher grain yield was recorded with the application of Zn. The per cent increase in grain yield with $\mathrm{Zn}$ application was 9.7 over no zinc application. The increase in grain yield on zinc addition might be due to enhanced formation of growth hormones such as auxin. Further, it also promotes starch formation and seed maturation. Such a response to application of zinc in deficient soil was quite obvious. Similar findings were reported by Keram et al. [18]. Application of boron @ $1 \mathrm{~kg} \mathrm{ha}^{-1}$ also increased the grain yield of wheat. The per cent increase in grain yield with B application was 8.1 over no B application. The increase in grain yield of wheat on boron application might be due to positive role of B in reproductive physiology essential for grain formation and development in the boron deficient soil Agarwal et al. [19]. Beneficial effects of $B$ on grain yield of wheat have also been reported by other workers Debnath et al. and Nadim et al. [20,21].

\section{References}

1. Jackson ML (1973) Soil Chemical Analysis. Prentice Hall Inc Englewood Cliffs, New Jersey, USA.

2. Black CA (1965) Methods of soil analysis. Part II Chemical and mineralogical properties, American Society of Agronomy, Madison, Wisconsin, USA.
3. Hatcher JT, LV Wilcox (1950) Colorimetric determination of boron using carmine. Analytical chemistry 22(4): 567-569.

4. AbEl-Hady BA (2007) Effect of zinc application on growth and nutrient uptake of barley plant irrigated with saline water. Journal of Applied Sciences Research 3(6): 431-436.

5. Das DK (2011) Introductory Soil Science. Kalyani Publishers, New Delhi, India.

6. Yadav GL (1991) Effect of irrigation regimes, nitrogen and zinc fertilization on the uptake of major nutrients (NPK) in late sown wheat on vertisols of Chambal command. Annals of Agricultural Research 12(4): 398-402.

7. Patel MS, Golakiya BA (1986) Effect of calcium carbonate and boron application on yield and nutrient uptake by groundnut. Journal of the Indian Society of Soil Science 84: 815-820.

8. Reeve E, Shive JW (1994) Potassium boron synergism in the nutrition of rice (Oryze sativa). Journal of the Indian Society of Soil Science 42(4): 563-564.

9. Lin HH, Zhang W, Xiao Y, Ying F, Chun WU (2007) Effects of different nitrogen fertilizer levels on $\mathrm{Fe}, \mathrm{Mn}, \mathrm{Cu}$ and $\mathrm{Zn}$ concentrations in shoot and grain quality in rice (Oryza sativa). Rice Science 14(4): 289-294.

10. Ai-Qing Z, Qiong-Li B, Xiao-Hong T, Xin-Chun, Gale W (2011) Combined effect of iron and zinc on micronutrient levels in wheat (Triticum aestivum L). Journal of Environmental Biology 32(2): 235-239.

11. Kaur R (2012) Influence of zinc and boron on wheat productivity and phosphorus use efficiency in an acid Alfisol M Sc Thesis Department of Soil Science, CSK Himachal Pradesh Krishi Vishvavidyalaya, Palampur, India.

12. Narwal RP, Malik RS (2011) Interaction of zinc with other nutrients. Indian Journal of Fertilizers 7(10): 140-150.

13. Sinha RB, Sakal R (1983) Effect of zinc and iron application in calcareous soil on zinc and iron nutrition of rice. Journal of the Indian Society of Soil Science 31(4): 527-533.

14. Chaudhary FM, Loneragan JF, Sharif M, Latif A, Quareshi RH (1973) Zinccopper antagonism in the nutrition of rice (Oryza sativa $L$ ). Plant and Soil 38(3): 573-580.

15. Hellal FA, Tallab AS, Safaa AM (2009) Influence of nitrogen and boron nutrition on nutrient balance and sugar beet yield grown in calcareous soil. Ozean Journal of Applied Sciences 2(1): 1-8.

16. Mattas KK, Uppal RS, Singh RP (2011) Effect of varieties and nitrogen management on the growth, yield and nitrogen uptake of durum wheat. Research Journal of Agricultural Sciences 2(2): 376-380.

17. Roshan NM, Azarpour E, Moradi M (2011) Study effects of different N and micronutrients fertilizer rates on yield and yield components of rice. World Applied Sciences Journal 13(3): 419-423.

18. Keram KS, Sharma BL, Sawarkar SD (2012) Impact of Zn application on yield, quality, nutrients uptake and soil fertility in a medium deep black soil (vertisol). International Journal of Science and Environment 1(5): 563-571.

19. Agarwal BK, Kumar B, Singh RN, Karmakar S, Shahi DK, et al. (2007) Effects of NPK and boron on yield and quality of wheat (Triticum aestivum L) in lithic haplustalf soil of east singhbhum. Indian Journal of Crop Science 2(2): 391-394.

20. Debnath MR, Jahiruddin M, Rahman MM, Haque MA (2011) Determining optimum rate of $\mathrm{B}$ application for higher yield of wheat in old Brahmaputra floodplain soil. Journal of Bangladesh Agricultural University 9(2): 205-210.

21. Nadim MA, Inayat UA, Mohammad SB, Ejaz AK, Muhammad Z, et al. (2011) Effect of micronutrient on growth and yield. Pakistan Journal of Agricultural Science 35(1-2): 113-119. 


$\begin{array}{ll}\text { BIOMEDICAL } & \text { Assets of Publishing with us } \\ \text { RESEARCHES } & \text { Global archiving of articles }\end{array}$

